\title{
Association between the IL-10 and IL- 6 polymorphisms and brucellosis susceptibility: a meta-analysis
}

\author{
Xiaochun $\mathrm{Jin}^{1 \dagger}$, Yueyuan $\mathrm{Wu}^{2 \dagger}$, Shuzhou Yin ${ }^{1 \dagger}, \mathrm{Xu} \mathrm{Chen}^{2^{*}}$ and Youtao Zhang ${ }^{2^{*}}$
}

\begin{abstract}
Background: Brucellosis is a quite normal zoonotic infection, which is caused by immediate contact with animals infected with Brucella or its products. IL-10 (- $1082 \mathrm{G} / \mathrm{A},-819 \mathrm{C} / \mathrm{T},-592 \mathrm{C} / \mathrm{A})$ and IL-6 -174 G/C polymorphisms have a great relationship with IL-10 and IL-6 production, which brings about Brucellosis pathogenesis and development. So far, the results of published literatures were controversial. Now, we perform a meta-analysis in different ethnic populations to get a more precise estimate of above polymorphisms with Brucellosis susceptibility.

Methods: Both OR and corresponding $95 \% \mathrm{Cl}$ were enrolled to make an assessment of the association strength through extracting genotyping frequency of cases and controls. The X2-test based Q-statistic and $I^{2}$ statistics were applied. If there was no evident heterogeneity, the fixed-effects model would be applied. If not, the random-effects model would be used.

Results: The significant associations were only found in Asian population of -819 loci under three genetic models as follows: (Allele model: $\mathrm{OR}=0.60,95 \% \mathrm{Cl}=0.44-0.82, P=0.001$ ), (homozygote comparison: $\mathrm{OR}=0.24,95 \% \mathrm{Cl}=0.09-0.62$, $P=0.003$ ), (recessive genetic model: $\mathrm{OR}=0.22,95 \% \mathrm{Cl}=0.05-0.91, P=0.036$ ).

Conclusion: In conclusion, IL-10 - 819 loci polymorphism contributes no risk to Caucasian population but may be associated with decreased risk in Asian population. And IL-10 -1082 G/A, 592 loci and IL-6-174 G/C polymorphism are not associated with Brucellosis risk.
\end{abstract}

Keywords: Brucellosis, Interleukin-10, Interleukin-6, Polymorphism, Meta-analysis

\section{Background}

Brucellosis is a quite normal zoonotic infection, which is caused by immediate contact with animals infected with Brucella or its products. Although the number of Brucellosis patients is relatively small, it remains a severe problem and it is very popular locally in most areas of Asia and Africa [1,2]. Some patients show onset fever, some show fatigue or sweating. Multiple clinical manifestations can be shown by Brucellosis. What's worse, nontypical clinical presentation brings difficulties to

\footnotetext{
* Correspondence: 934944882@qq.com; zhangyoutao196511@126.com

${ }^{+}$Xiaochun Jin, Yueyuan Wu and Shuzhou Yin are co-first authors

${ }^{2}$ Department of Clinical Laboratory, First Affiliated Hospital of Soochow University, 188 Shizi Road, Suzhou 215006, People's Republic of China Full list of author information is available at the end of the article
}

diagnosis. The exact pathogenesis of Brucellosis remains unknown. It has been reported that cellmediated immunity is considered to play a crucial role in immunity response to Brucellosis infection [3]. $\mathrm{CD} 4^{+}$and $\mathrm{CD} 8^{+} \mathrm{T}$ lymphocytes are considered as playing a key role in cellular immunity as they can release IFN- $\lambda$ and activate the functions in macrophages [4, 5]. Additionally, Interleukin-10 (IL10) is a crucial cytokine contributing to resist inflammation, which makes various biological effects on multiple types of cell. After the infection of Brucella pathogen, IL-10 can lead to the production drawdown of IFN- $\lambda$ and inhibition of macrophages function [6].

(c) The Author(s). 2020 Open Access This article is licensed under a Creative Commons Attribution 4.0 International License, which permits use, sharing, adaptation, distribution and reproduction in any medium or format, as long as you give appropriate credit to the original author(s) and the source, provide a link to the Creative Commons licence, and indicate if changes were made. The images or other third party material in this article are included in the article's Creative Commons licence, unless indicated otherwise in a credit line to the material. If material is not included in the article's Creative Commons licence and your intended use is not permitted by statutory regulation or exceeds the permitted use, you will need to obtain permission directly from the copyright holder. To view a copy of this licence, visit http://creativecommons.org/licenses/by/4.0/ The Creative Commons Public Domain Dedication waiver (http://creativecommons.org/publicdomain/zero/1.0/) applies to the data made available in this article, unless otherwise stated in a credit line to the data. 
IL-6 is another cytokine, not only involving in the process of inflammation response but also regulating multiple biological processes such as metabolism, regeneration and nervous system [7]. It has been demonstrated that polymorphism can influence the expression of cytokine and play a crucial role in infectious diseases $[8,9]$.

There are quite a few literatures demonstrating that hereditary factors play crucial parts in the development of Brucellosis [10-14]. Apart from IL-6 -174 G/C polymorphism, a large number of documents have focused on IL-10 promoter polymorphisms, including position $-1082(\mathrm{G} \rightarrow \mathrm{A})$ $(\mathrm{rs} 1800896), \quad-819(\mathrm{C} \rightarrow \mathrm{T}) \quad(\mathrm{rs} 1800871) \quad$ and $592(\mathrm{C} \rightarrow \mathrm{A}) \quad(\mathrm{rs} 1800872)$. However, inconsistent results were obtained. In the present study, we carry out a meta-analysis to obtain a more precise estimate of the above polymorphisms. In addition, the present study is a multi-ethnic study because ethnic populations may contribute tremendous influence to genetic polymorphisms of IL-10 and IL-6.

\section{Methods}

\section{Search strategy}

The present meta-analysis was performed on account of predefined protocol named Meta-analysis Of Observational Studies in Epidemiology (MOOSE) group [15]. Two databases consisting of PubMed and Embase were put into use by searching keywords as follows: ("IL" or "Interleukin") and "Brucellosis" and "polymorphism". The expiration date was the end of February, 2020. We reviewed titles and abstracts of all citations and retrieved studies. We did not limit anything of literatures such as its language, regional culture, publication year and sample size. After these studies were received, their corresponding references were also investigated for other possible studies.

\section{Inclusion and exclusion criteria}

The inclusion criteria consisted of three items: (a) a case-control research or short communication; (b) assessment of relationship between IL polymorphisms and Brucellosis susceptibility; (c) providing enough data to judge the final result or the present data can predict the final result. Accordingly, other types of research were excluded such as case report, review article.

\section{Data extraction}

The whole information and data were independently extracted by first author (Yueyuan Wu, Shuzhou Yin and Xiaochun Jin) and the final information was reviewed by final referees $(\mathrm{Xu}$ Chen and Youtao Zhang). The present study is a multi-ethnic study.
Different ethnic descents were categorized as African, Asian, and Caucasian. To get a accurate result, three authors (Shuzhou Yin, Yueyuan Wu and Xiaochun Jin) were asked to check all data and information. If they could not reach an agreement, they would check the above data and information again and have a meeting trying to come to an agreement. If the controversial results still existed, the final referees (Xu Chen and Youtao Zhang) would be asked to give the final decision.

\section{Methodological quality assessment}

Three authors (Shuzhou Yin, Yueyuan Wu and Xiaochun Jin) were asked to perform methodological quality evaluation according to predefined assessment criteria (Table 1), which was based on the items of Jiang et al. [16]. The scores with the range of 0 (lowest) to 18(highest) were based on several assessment items consisting of credibility of controls, matching criteria, diagnostic criteria, genotyping examination, sample size and Hardy-Weinberg equilibrium. The above assessment items were performed based on popular epidemiological methods and Brucellosis

Table 1 Detailed evaluation criteria focused on included studies

\begin{tabular}{ll}
\hline Criterion of evaluation & score \\
\hline Reliability of controls & 3 \\
Live in the area locally & 2 \\
Volunteers who conduct blood or organ transplant & 1 \\
Patients who is not related with Brucellosis & 0 \\
Not reported or cannot get the detailed information & \\
Matching standard & 3 \\
All including age, sex and ethnicity & 1.5 \\
Ethnicity only & 0 \\
Not reported or cannot get the detailed information & \\
Diagnosis of Brucellosis & 3 \\
According to clinical manifestation and high antibodies & 1.5 \\
According to history or other examination & 0 \\
Not reported or cannot get the detailed information & \\
Genotyping methods & 3 \\
by "blinded" status & 3 \\
Not reported or cannot get the detailed information & 0 \\
Hardy-Weinberg equilibrium & 3 \\
The compliance is good & 3 \\
Not reported or cannot get the detailed information & \\
More than 500 & \\
\hline less than 100 & 3 \\
\hline
\end{tabular}




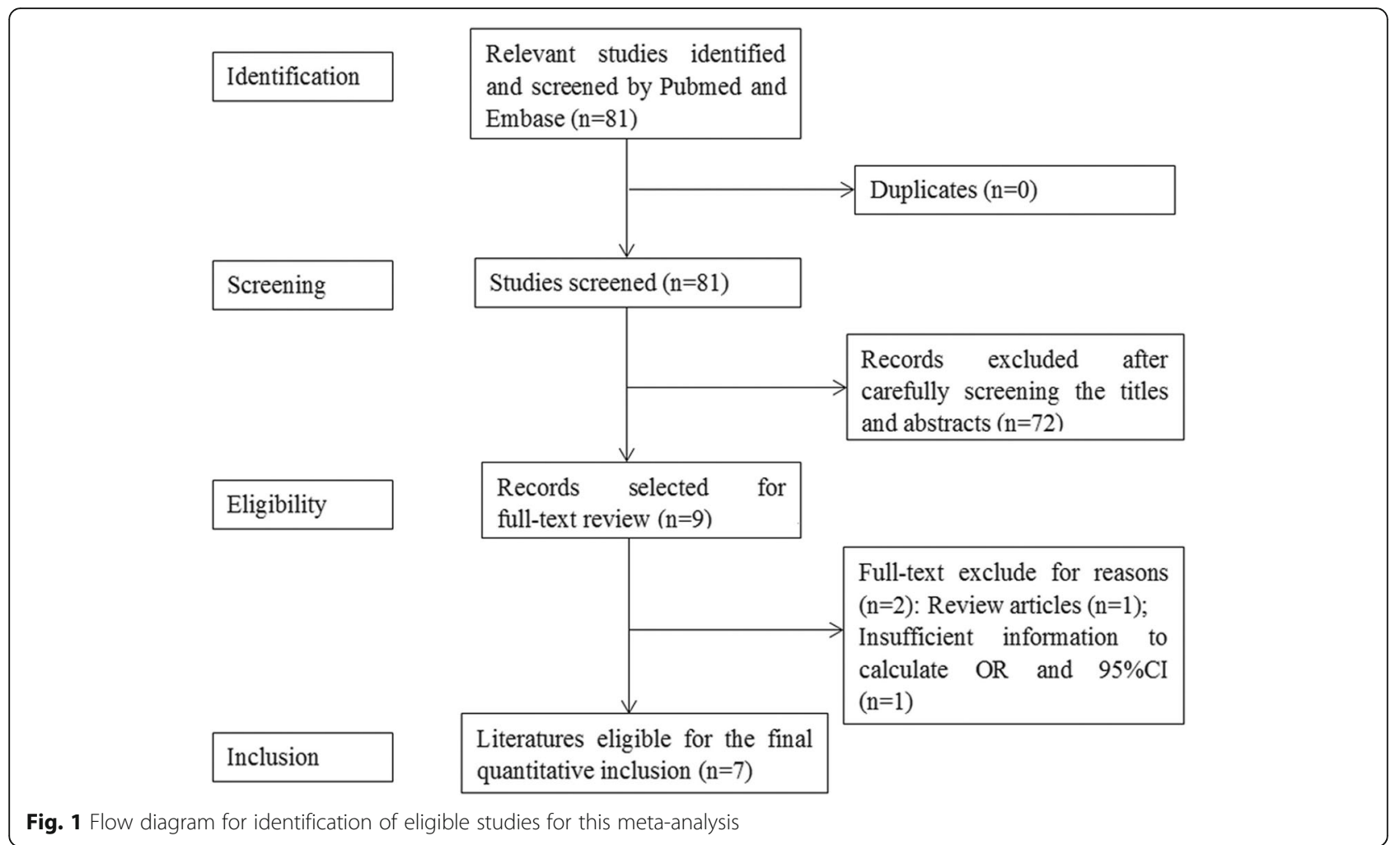

special characteristic. Literatures whose scores less than 12 were considered as "low-quality" literatures. However, the literatures with scores equal to or more than 12 were regarded as "high-quality" studies.

\section{Statistical analysis}

Both the OR and 95\%CI were estimated to make the assessment of association power in four different genetic models. For position $-174 \mathrm{G} / \mathrm{C}$ of IL-6, there were allele comparison ( $G$ versus $C$ ), homozygote comparison (GG versus CC), recessive model (GG versus $\mathrm{GC} / \mathrm{CC}$ ), and dominant model (GG/GC versus $\mathrm{CC})$. For position $-1082 \mathrm{G} / \mathrm{A}$ of IL-10, there were allele comparison (A versus $\mathrm{G}$ ), homozygote comparison (AA versus $G G$ ), recessive model (AA versus AG/GG), and dominant model (AA/AG versus GG). For position $-819 \mathrm{C} / \mathrm{T}$ of $\mathrm{IL}-10$, there were allele comparison ( $\mathrm{T}$ versus $\mathrm{C}$ ), homozygote comparison (TT versus CC), recessive model (TT versus $\mathrm{TC} /$ $\mathrm{CC})$, and dominant model (TT/TC versus CC). For

Table 2 Characteristics of studies included in this meta-analysis

\begin{tabular}{|c|c|c|c|c|c|c|c|}
\hline Literature & $\begin{array}{l}\text { Country } \\
\text { (Ethnics) } \\
\end{array}$ & $\begin{array}{l}\text { Genotyping } \\
\text { methods }\end{array}$ & $\begin{array}{l}\text { Source of } \\
\text { control }\end{array}$ & $\begin{array}{l}\text { Sample size (Case/ } \\
\text { Control) }\end{array}$ & Studied polymorphism & $\begin{array}{l}\text { conformity of } \\
\text { HWE }\end{array}$ & $\begin{array}{l}\text { Quality } \\
\text { score }\end{array}$ \\
\hline $\begin{array}{l}\operatorname{Bravo}(2003) \\
{[10,12]}\end{array}$ & $\begin{array}{l}\text { Caucasian } \\
\text { (Spain) }\end{array}$ & PCR-SSP & PB & $83 / 101$ & IL-10(-1082,-819,-592) & Yes & 14 \\
\hline Budak(2007) [20] & $\begin{array}{l}\text { Caucasian } \\
\text { (Turkey) }\end{array}$ & PCR-SSP & PB & $40 / 50$ & $\begin{array}{l}\text { IL-10(-1082,-819,-592); IL- } \\
6(-174)\end{array}$ & Yes & 12 \\
\hline Bravo(2008) [25] & $\begin{array}{l}\text { Caucasian } \\
\text { (Spain) }\end{array}$ & PCR-SSP & PB & $82 / 102$ & IL-6(-174) & Yes & 13 \\
\hline $\begin{array}{l}\text { Rasouli(2008) } \\
\text { [22] }\end{array}$ & Asian (Iran) & PCR-RFLP & PB & $190 / 81$ & IL-10(-1082,-819,-592) & Yes & 13 \\
\hline $\begin{array}{l}\text { Karaoglan(2009) } \\
{[21]}\end{array}$ & $\begin{array}{l}\text { Caucasian } \\
\text { (Turkey) }\end{array}$ & PCR-SSP & PB & $85 / 85$ & $\begin{array}{l}\| \mathrm{L}-10(-1082,-819) ; \mid \mathrm{L}- \\
6(-174)\end{array}$ & Yes & 13 \\
\hline Asaei(2013) [24] & Asian (Iran) & PCR-RFLP & PB & $196 / 82$ & $\mid \mathrm{L}-6(-174)$ & Yes & 14 \\
\hline $\begin{array}{l}\text { Kazemi(2016) } \\
{[23]}\end{array}$ & Asian (Iran) & PCR-RFLP & PB & $60 / 60$ & $\begin{array}{l}\text { IL-10(-1082,-819,-592); IL- } \\
6(-174)\end{array}$ & Yes & 13 \\
\hline
\end{tabular}


Table 3 The general results for the association between IL-10, IL-6 polymorphisms with Brucellosis risk

\begin{tabular}{|c|c|c|c|c|c|c|c|c|}
\hline \multirow[t]{2}{*}{ Comparison } & \multirow{2}{*}{$\begin{array}{l}\text { Group (sample } \\
\text { size) }\end{array}$} & \multicolumn{3}{|c|}{ Test of association } & \multirow[t]{2}{*}{ Mode } & \multicolumn{3}{|c|}{ Test of Heterogeneity } \\
\hline & & $\overline{\mathrm{OR}}$ & $95 \% \mathrm{Cl}$ & $P$ & & $\overline{x^{2}}$ & $P$ & $1^{2}$ \\
\hline \multicolumn{9}{|l|}{ IL-6-174 (G $\rightarrow C)$} \\
\hline \multirow[t]{3}{*}{$G$ versus. $C$} & Overall(452/377) & 1.09 & $0.87-1.36$ & 0.468 & Fixed & 1.27 & 0.867 & 0 \\
\hline & Caucasian(202/235) & 1.09 & $0.82-1.46$ & 0.544 & Fixed & 1.14 & 0.567 & 0 \\
\hline & Asian(250/142) & 1.07 & $0.76-1.52$ & 0.685 & Fixed & 0.13 & 0.724 & 0 \\
\hline \multirow[t]{3}{*}{ GG versus. CC } & Overall(452/377) & 1.28 & $0.71-2.28$ & 0.410 & Fixed & 4.33 & 0.363 & 7.7 \\
\hline & Caucasian(202/235) & 1.15 & $0.43-3.12$ & 0.780 & Fixed & 3.61 & 0.164 & 44.6 \\
\hline & Asian(250/142) & 1.78 & $0.69-4.55$ & 0.232 & Fixed & 0 & 0.976 & 0 \\
\hline \multirow[t]{3}{*}{ GG versus. CC/GC } & Overall(452/377) & 1.03 & $0.77-1.38$ & 0.852 & Fixed & 3.64 & 0.457 & 0 \\
\hline & Caucasian(202/235) & 1.04 & $0.63-1.73$ & 0.869 & Fixed & 3.37 & 0.185 & 40.7 \\
\hline & Asian(250/142) & 0.97 & $0.62-1.52$ & 0.905 & Fixed & 0.15 & 0.699 & 0 \\
\hline \multirow[t]{3}{*}{ GG/GC versus. CC } & Overall(452/377) & 1.30 & $0.62-2.73$ & 0.487 & Fixed & 6.95 & 0.138 & 42.5 \\
\hline & Caucasian(202/235) & 1.16 & $0.35-3.87$ & 0.809 & Random & 5.53 & 0.063 & 63.8 \\
\hline & Asian(250/142) & 1.87 & $0.74-4.71$ & 0.184 & Fixed & 0.02 & 0.891 & 0 \\
\hline \multicolumn{9}{|l|}{ IL-10-1082 (G $\rightarrow A)$} \\
\hline \multirow[t]{3}{*}{ A versus. $G$} & Overall(458/377) & 0.82 & $0.62-1.08$ & 0.152 & Fixed & 6.94 & 0.139 & 42.4 \\
\hline & Caucasian(208/236) & 0.76 & $0.49-1.18$ & 0.217 & Random & 4.90 & 0.086 & 59.1 \\
\hline & Asian(250/141) & 0.89 & $0.58-1.37$ & 0.602 & Fixed & 1.78 & 0.182 & 44.0 \\
\hline \multirow[t]{3}{*}{ AA versus. GG } & Overall(458/377) & 1.51 & $0.87-2.60$ & 0.142 & Fixed & 5.07 & 0.281 & 21.1 \\
\hline & Caucasian(208/236) & 1.36 & $0.58-3.18$ & 0.484 & Random & 4.20 & 0.123 & 52.4 \\
\hline & Asian(250/141) & 1.95 & $0.83-4.58$ & 0.124 & Fixed & 0.37 & 0.544 & 0 \\
\hline \multirow[t]{3}{*}{ AA versus. GG/GA } & Overall(458/377) & 0.80 & $0.49-1.30$ & 0.360 & Random & 9.76 & 0.045 & 59 \\
\hline & Caucasian(208/236) & 0.62 & $0.39-0.98$ & 0.043 & Fixed & 2.75 & 0.252 & 27.4 \\
\hline & Asian(250/141) & 1.42 & $0.39-5.23$ & 0.598 & Random & 4.66 & 0.031 & 78.5 \\
\hline \multirow[t]{3}{*}{ AA/GA versus. GG } & Overall(458/377) & 0.72 & $0.39-1.32$ & 0.291 & Fixed & 7.06 & 0.133 & 43.4 \\
\hline & Caucasian(208/236) & 0.96 & $0.44-2.09$ & 0.916 & Random & 2.75 & 0.126 & 51.7 \\
\hline & Asian(250/141) & 0.42 & $0.19-0.94$ & 0.035 & Fixed & 4.66 & 0.678 & 0 \\
\hline \multicolumn{9}{|l|}{$-819(C \rightarrow T)$} \\
\hline \multirow[t]{3}{*}{ T versus. $C$} & Overall(458/377) & 0.90 & $0.62-1.31$ & 0.587 & Random & 11.71 & 0.02 & 65.8 \\
\hline & Caucasian(208/236) & 1.22 & $0.91-1.63$ & 0.190 & Fixed & 1.28 & 0.528 & 0 \\
\hline & Asian(250/141) & 0.60 & $0.44-0.82$ & 0.001 & Fixed & 0.02 & 0.889 & 0 \\
\hline \multirow[t]{3}{*}{$\Pi$ versus. CC } & Overall(458/377) & 0.71 & $0.28-1.81$ & 0.471 & Random & 9.96 & 0.041 & 59.8 \\
\hline & Caucasian(208/236) & 1.22 & $0.56-2.65$ & 0.615 & Fixed & 2.54 & 0.280 & 21.4 \\
\hline & Asian(250/141) & 0.24 & $0.09-0.62$ & 0.003 & Fixed & 0.15 & 0.694 & 0 \\
\hline \multirow[t]{3}{*}{$\pi$ versus. $\mathrm{CC} / \mathrm{TC}$} & Overall(458/377) & 0.68 & $0.28-1.65$ & 0.393 & Random & 9.77 & 0.044 & 59.1 \\
\hline & Caucasian(208/236) & 1.15 & $0.60-2.23$ & 0.670 & Fixed & 1.96 & 0.375 & 0 \\
\hline & Asian(250/141) & 0.22 & $0.05-0.91$ & 0.036 & Fixed & 1.30 & 0.254 & 23.2 \\
\hline \multirow[t]{3}{*}{ TT/TC versus. CC } & Overall(458/377) & 1.33 & $0.73-2.44$ & 0.353 & Random & 15.88 & 0.003 & 74.8 \\
\hline & Caucasian(208/236) & 1.31 & $0.90-1.90$ & 0.160 & Fixed & 0.44 & 0.802 & 0 \\
\hline & Asian(250/141) & 1.62 & $0.19-13.80$ & 0.658 & Random & 13.99 & 0 & 92.9 \\
\hline \multicolumn{9}{|l|}{$-592(C \rightarrow A)$} \\
\hline \multirow[t]{3}{*}{ A versus. $C$} & Overall(373/292) & 0.90 & $0.64-1.26$ & 1.524 & Fixed & 7.56 & 0.109 & 47.1 \\
\hline & Caucasian(123/151) & 1.05 & $0.70-1.56$ & 0.813 & Fixed & 2.21 & 0.331 & 9.6 \\
\hline & Asian(250/141) & 0.78 & $0.44-1.38$ & 0.393 & Random & 3.55 & 0.059 & 71.9 \\
\hline
\end{tabular}


Table 3 The general results for the association between IL-10, IL-6 polymorphisms with Brucellosis risk (Continued)

\begin{tabular}{|c|c|c|c|c|c|c|c|c|}
\hline \multirow[t]{2}{*}{ Comparison } & \multirow{2}{*}{$\begin{array}{l}\text { Group (sample } \\
\text { size) }\end{array}$} & \multicolumn{3}{|c|}{ Test of association } & \multirow[t]{2}{*}{ Mode } & \multicolumn{3}{|c|}{ Test of Heterogeneity } \\
\hline & & $\overline{\mathrm{OR}}$ & $95 \% \mathrm{Cl}$ & $P$ & & $\overline{x^{2}}$ & $P$ & $1^{2}$ \\
\hline \multirow[t]{3}{*}{ AA versus. CC } & Overall(373/292) & 0.58 & $0.32-1.06$ & 0.076 & Fixed & 4.49 & 0.344 & 10.9 \\
\hline & Caucasian(123/151) & 0.77 & $0.32-1.85$ & 0.564 & Fixed & 0.76 & 0.683 & 0 \\
\hline & Asian(250/141) & 0.48 & $0.14-1.67$ & 0.248 & Random & 2.99 & 0.084 & 66.5 \\
\hline \multirow[t]{3}{*}{$A A$ versus. CC/CA } & Overall(373/292) & 0.63 & $0.37-1.07$ & 0.086 & Fixed & 2.91 & 0.573 & 0 \\
\hline & Caucasian(123/151) & 0.86 & $0.38-1.94$ & 0.710 & Fixed & 0.05 & 0.167 & 0 \\
\hline & Asian(250/141) & 0.51 & $0.19-1.33$ & 0.168 & Random & 1.91 & 0.078 & 47.7 \\
\hline \multirow[t]{3}{*}{$\mathrm{AA} / \mathrm{CA}$ versus. $\mathrm{CC}$} & Overall(373/292) & 0.80 & $0.51-1.26$ & 0.345 & Fixed & 6.10 & 0.192 & 34.4 \\
\hline & Caucasian(123/151) & 0.78 & $0.34-1.80$ & 0.567 & Fixed & 3.89 & 0.235 & 30.9 \\
\hline & Asian(250/141) & 0.80 & $0.40-1.67$ & 0.535 & Random & 3.15 & 0.076 & 68.2 \\
\hline
\end{tabular}

position - 592 loci of IL-10, there were allele comparison (A versus $\mathrm{C}$ ), homozygote comparison (AA versus $C C$ ), recessive model (AA versus $A C / C C$ ), and dominant model (AA/AC versus $\mathrm{CC}$ ). The $\mathrm{X}^{2-}$ test based Q-statistic and $\mathrm{I}^{2}$ statistics were used. If there was no evident heterogeneity, the fixed-effects model would be applied [17]. If not, the random-effects model would be used [18]. Sensitivity analysis was used to evaluate the stability of the results. Funnel plots and Egger's test were applied to detect the potential publication bias [19]. All statistics were conducted using Stata software (version 12.0; StataCorp LP, College Station, TX, USA).
Study

ID
$\%$

OR $(95 \% \mathrm{Cl}) \quad$ Weight

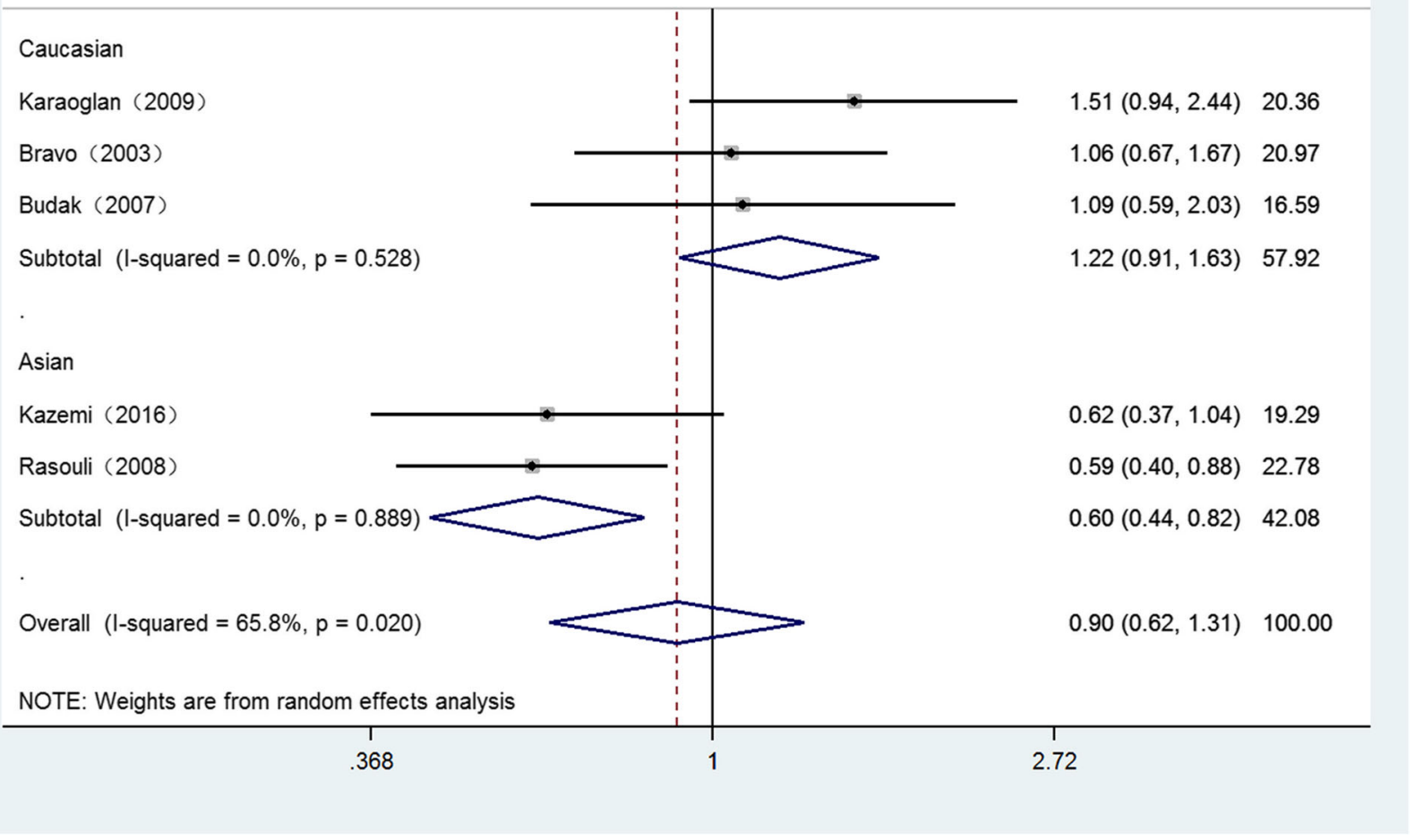

Fig. 2 Forest plot of IL-10 -819 C/T polymorphism on Brucellosis risk in allele model (T vs. C) 


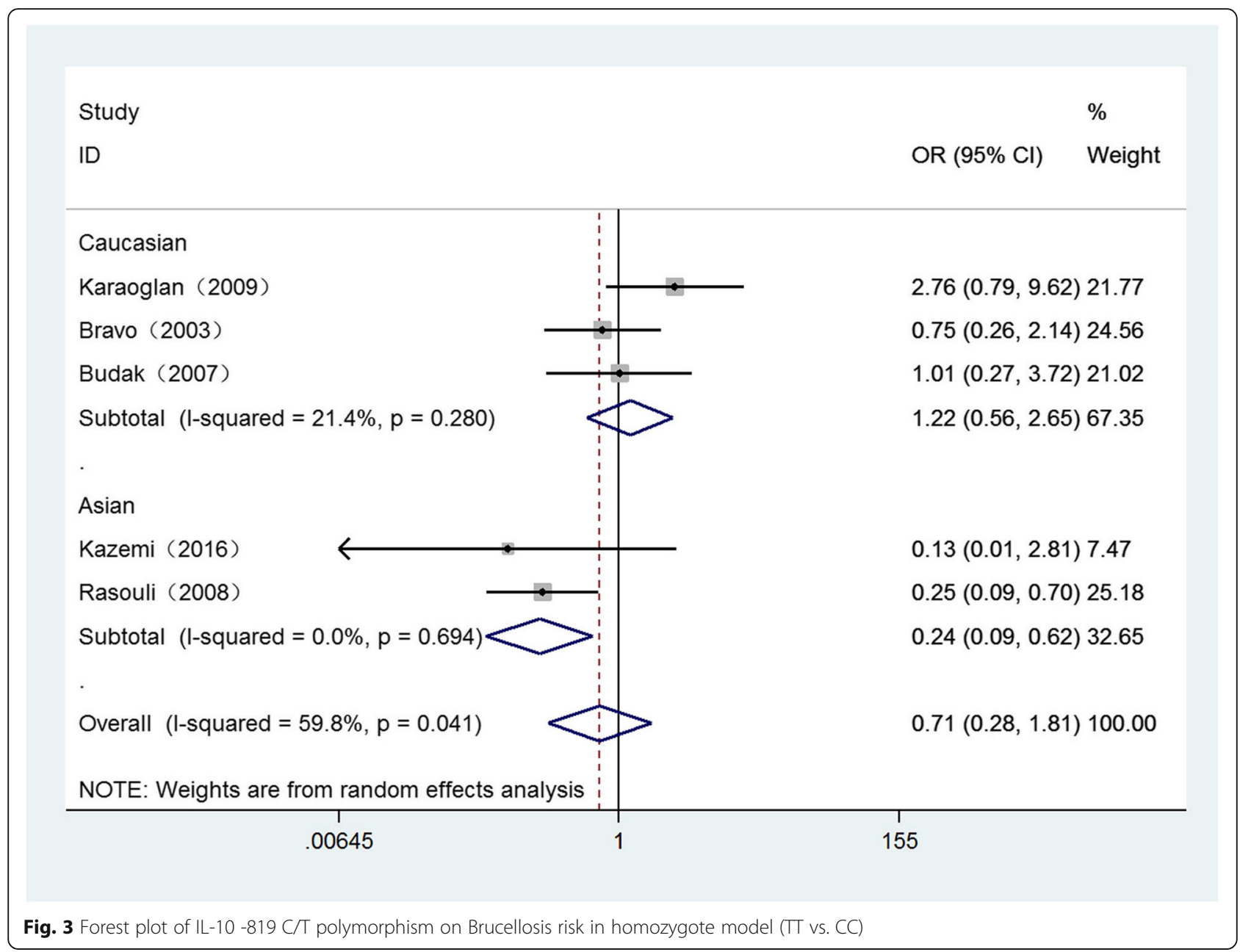

\section{Results}

\section{Eligible studies}

A flow chart of the search course is displayed in Fig. 1. Seven literatures were enrolled in our metaanalysis [10, 20-25]. The detailed information of seven studies was listed in Table 2.

\section{Quantitative synthesis of data}

Detailed results for the relationship between these polymorphisms and Brucellosis susceptibility are displayed in Table 3. $P<0.05$ is considered as a significant association. Overall, significant associations were only found in Asian population of -819 loci under three genetic models as follows: (Allele model: $\mathrm{OR}=0.60,95 \% \mathrm{CI}=0.44-0.82, P=$ 0.001) (Fig. 2), (homozygote comparison: $\mathrm{OR}=0.24$, $95 \% \mathrm{CI}=0.09-0.62, P=0.003$ ) (Fig. 3 ), (recessive genetic model: $\mathrm{OR}=0.22,95 \% \mathrm{CI}=0.05-0.91, P=0.036$ ) (Fig. 4).

\section{Sensitivity analysis and publication Bias}

Sensitivity Analysis was carried out to indicate single literature's effect on the final result through continuous removal of individual studies under every genetic model.
In the present study, our results could not be affected by any study, suggesting its reliability and robustness. Although slightly asymmetrical funnel plots were discovered $(P=0.806)$, we could not find any distinct publication bias by Egger's test under allele model $(P=0.509)$ or recessive model $(P=0.509)$.

\section{Discussion}

Previous studies have explored the association of IL-10 and IL-6 polymorphisms with Brucellosis risk. The present meta-analysis consists of 7 studies for IL-10 and IL-6 polymorphisms. To the best of our knowledge, the present research was the first to investigate the relationship between IL-10 and IL-6 polymorphisms and Brucellosis risk. Our meta-analysis shows that IL-10 -819 loci polymorphism contributes no risk to Caucasian population but may be associated with decreased risk in Asian population. And other polymorphisms of IL-10 and IL-6 are not related with Brucellosis susceptibility. For IL-6 $-174 \mathrm{G} / \mathrm{C}$ polymorphism, Budak et al. reported in 2007 that GG genotype was more common in patients of Brucellosis than healthy controls ( 40 cases and 50 controls) 


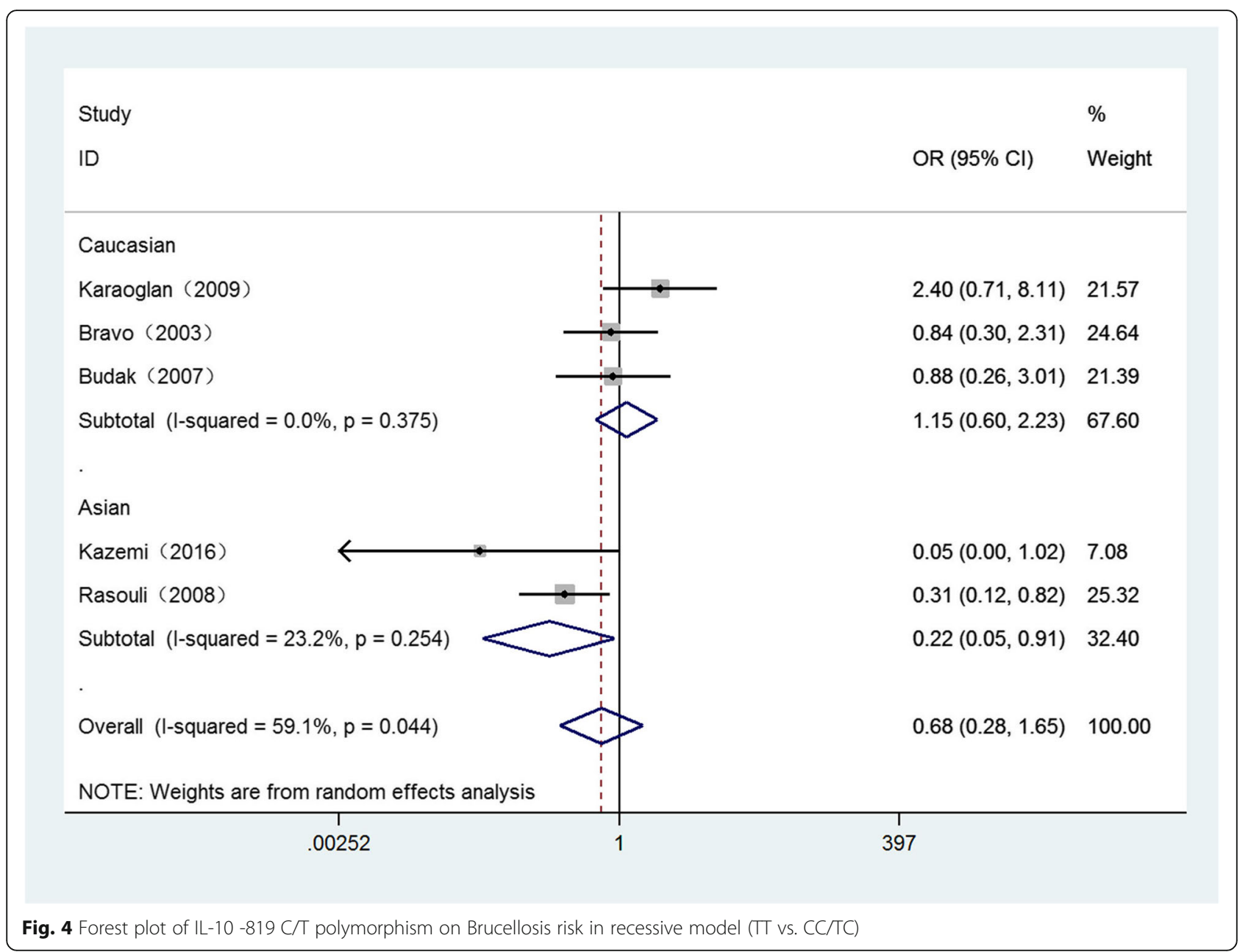

and concluded that GG genotype was a risk factor in the development of Brucellosis [20]. However, the other four literatures reported no association between IL-6 -174 G/ $\mathrm{C}$ polymorphism and Brucellosis susceptibility. We consider sample size as an important factor contributing to the above discrepancy. Small-study bias is not an emerging event when performing genetic association studies [26]. The current result of IL-10 -819 loci polymorphism may be attributed to race. It is wellknown that different races have discrepant genotype number and allele frequency. So that it is necessary to conduct subgroup analysis by race. However, we made a conservative conclusion. Only two literatures with 250 cases and 141 controls were enrolled in our study. Considering the small sample size of eligible studies, a new updated study needs to be urgently conducted. Regarding the significant association found at IL10-1082 AA genotyping in Caucasian, we feel that it is likely a false positive, which is based on two reasons. Firstly, the $P$ value approximates 0.05 and is a critical value. Secondly, the $P$ values of other genetic models are $0.217,0.484$, and $0.916(P>0.05)$.

Extensive variations have been established in the frequencies of cytokine polymorphism among different healthy population, including the $-1082 \mathrm{G} / \mathrm{A}$ polymorphism, which has been investigated most widely in healthy populations. The allele frequency show wide difference in different countries and regions. For example, the prevalence rate of IL-10 -1082 G allele was reported to be $42.5,48.93 .8$ and $13.0 \%$ in Iranians, Norwegians, Japanese and Koreans, respectively [27-30].

HWE has been demonstrated to be an important genetic equilibrium law. And if the genotype distribution of control population is not conforming to HWE law, selection bias would occur. It has been reported that several factors would contribute to HWE deviation including fixed mating, or allele do not achieve equilibrium condition and other possible factors, which may lead to inaccurate results of meta-analysis. In our meta-analysis, the problem contributes little influence on our results. Because genotype 
distributions of all studies are consistent with HWE, which improves reliability of our results greatly.

Genome-wide association study (GWAS) is undoubtedly an effective method to find the sequence of gene mutations, accordingly screening the specific SNP associated with disease. GWAS opens the door to the study of complex diseases by comparing patients' SNP sites with control groups in whole genome, which identifies all variant allele mutation frequencies. It is regrettable that there is rare GWAS on Brucellosis. Sankarasubramanian etal pulished a study titled "Identification of genetic variants of Brucella spp. through genome-wide association studies" and they found special SNPs, which were closely related with human's specificity and virulence. They also thought that origin of these special SNPs was early and might derive from $B$. abortus evolution [31]. However, we think this is just a new start in exploring species-specific SNPs of Brucellosis. In the future, we should investigate further in the genomes and their roles of Brucellosis.

Despite a lot of work we have done, there are still disadvantages existing, which should be remarkable here. Firstly, the present research is still a smallsample study and we should be careful in the results. Secondly, some miscellaneous factors including age, sex and other environment factors are not considered and calculated for final estimates. So that the results of our meta-analysis are on the account of unadjusted estimates. We should also be careful in the results.

\section{Conclusion}

In conclusion, this is the first meta-analysis which investigates the association between IL-10 polymorphism and Brucellosis risk. In conclusion, IL-10 -819 loci polymorphism contributes no risk to Caucasian population but may be associated with decreased risk in Asian population. And IL-10 -1082 G/A, 592 loci and IL-6 -174 G/C polymorphism are not associated with Brucellosis risk.

\section{Abbreviations}

IL-10: Interleukin-10; IL-6: Interleukin-6; PB: Population-based; HWE: HardyWeinberg equilibrium; RFLP: Restricted Fragment Length Polymorphism; PM: Pneumococcal meningitis; MM: Meningococcal meningitis;

Cl: Confidence interval; OR: Odds ratio; SNP: Single nucleotide polymorphism

\section{Acknowledgements}

Not applicable.

\section{Authors' contributions}

Conceived and designed the experiments: $X C Y Z$; Performed the experiments: XJ YW SY XC YZ; Analyzed the data: XC YZ XJ YW SY; Contributed reagents/materials/analysis tools: XJ YW SY; Wrote the paper: XC $Y Z$. All authors have read and approved the manuscript.

\section{Funding}

The authors declare that there are no sources of funding to be acknowledged.

\section{Availability of data and materials}

All data generated or analysed during this study are included in this published article and its supplementary information files.

Ethics approval and consent to participate

Not applicable.

Consent for publication

Not applicable.

\section{Competing interests}

The authors declare that there are no competing interests associated with the manuscript

\section{Author details}

'Department of Anesthesiology, Suzhou Kowloon Hospital, Shanghai Jiaotong University School of Medcine, Suzhou 215028, People's Republic of China. ${ }^{2}$ Department of Clinical Laboratory, First Affiliated Hospital of Soochow University, 188 Shizi Road, Suzhou 215006, People's Republic of China.

Received: 25 May 2019 Accepted: 20 March 2020

Published online: 30 March 2020

\section{References}

1. Pappas G, Papadimitriou P, Akritidis N, Christou L, Tsianos EV. The new global map of human brucellosis. Lancet Infect Dis. 2006;6(2):91-9.

2. Boschiroli ML, Foulongne V, O'Callaghan D. Brucellosis: a worldwide zoonosis. Curr Opin Microbiol. 2001;4(1):58-64.

3. Golding B, Scott DE, Scharf O, Huang LY, Zaitseva M, Lapham C, Eller N, Golding $\mathrm{H}$. Immunity and protection against Brucella abortus. Microbes Infect. 2001:3(1):43-8.

4. Ko J, Splitter GA. Molecular host-pathogen interaction in brucellosis: current understanding and future approaches to vaccine development for mice and humans. Clin Microbiol Rev. 2003;16(1):65-78.

5. Araya LN, Elzer PH, Rowe GE, Enright FM, Winter AJ. Temporal development of protective cell-mediated and humoral immunity in BALB/C mice infected with Brucella abortus. J Immunol. 1989;143(10):3330-7.

6. Fernandes DM, Baldwin CL. Interleukin-10 downregulates protective immunity to Brucella abortus. Infect Immun. 1995;63(3):1130-3.

7. Seruga B, Zhang H, Bernstein LJ, Tannock IF. Cytokines and their relationship to the symptoms and outcome of cancer. Nat Rev Cancer. 2008;8(11):887-99.

8. Bidwell J, Keen L, Gallagher G, Kimberly R, Huizinga T, McDermott MF, Oksenberg J, McNicholl J, Pociot F, Hardt C, et al. Cytokine gene polymorphism in human disease: on-line databases, supplement 1. Genes Immun. 2001;2(2):61-70

9. Sepanjnia A, Eskandari-Nasab E, Moghadampour M, Tahmasebi A, Dahmardeh F. TGFbeta1 genetic variants are associated with an increased risk of acute brucellosis. Infect Dis Ther. 2015;47(7):458-64.

10. Bravo MJ, de Dios CJ, Alonso A, Caballero A. Polymorphisms of the interferon gamma and interleukin 10 genes in human brucellosis. Eur J Immunogenet. 2003:30(6):433-5.

11. Orozco G, Sanchez E, Lopez-Nevot MA, Caballero A, Bravo MJ, Morata P, de Dios CJ, Alonso A, Martin J. Inducible nitric oxide synthase promoter polymorphism in human brucellosis. Microbes Infect. 2003;5(13):1165-9.

12. Bravo MJ, Colmenero Jde D, Alonso A, Caballero A. HLA-B*39 allele confers susceptibility to osteoarticular complications in human brucellosis. J Rheumatol. 2003;30(5):1051-3.

13. Caballero A, Bravo MJ, Nieto A, Colmenero JD, Alonso A, Martin J. TNFA promoter polymorphism and susceptibility to brucellosis. Clin Exp Immunol. 2000:121(3):480-3.

14. Rezazadeh M, Hajilooi M, Haidari M, Rafiei A, Alavi SA, Keramat F. Association of susceptibility to brucellosis and interleukin-4 promoter polymorphism. Scand J Infect Dis. 2006;38(11-12):1045-9.

15. Stroup DF, Berlin JA, Morton SC, Olkin I, Williamson GD, Rennie D, Moher D, Becker BJ, Sipe TA, Thacker SB. Meta-analysis of observational studies in 
epidemiology: a proposal for reporting. Meta-analysis of observational studies in epidemiology (MOOSE) group. Jama. 2000;283(15):2008-12.

16. Jiang DK, Wang WZ, Ren WH, Yao L, Peng B, Yu L. TP53 Arg72Pro polymorphism and skin cancer risk: a meta-analysis. J Invest Dermatol. 2011; 131(1):220-8.

17. Mantel N, Haenszel W. Statistical aspects of the analysis of data from retrospective studies of disease. J Natl Cancer Inst. 1959;22(4):719-48.

18. DerSimonian R, Laird N. Meta-analysis in clinical trials. Control Clin Trials. 1986;7(3):177-88.

19. Begg CB, Mazumdar M. Operating characteristics of a rank correlation test for publication bias. Biometrics. 1994;50(4):1088-101.

20. Budak F, Goral G, Heper Y, Yilmaz E, Aymak F, Basturk B, Tore O, Ener B, Oral HB. IL-10 and IL-6 gene polymorphisms as potential host susceptibility factors in brucellosis. Cytokine. 2007;38(1):32-6.

21. Karaoglan I, Pehlivan S, Namiduru M, Pehlivan M, Kilincarslan C, Balkan Y, Baydar I. TNF-alpha, TGF-beta, IL-10, IL-6 and IFN-gamma gene polymorphisms as risk factors for brucellosis. New Microbiol. 2009;32(2):173-8.

22. Rasouli M, Kiany S, Behbin M. Interleukin-10 gene polymorphisms and susceptibility to brucellosis in Iranian patients. Iran J Immunol. 2008;5(2):131-5.

23. Kazemi S, Saidijam M, Hashemi SH, Karami M, Vaisi-Raygani A, Alikhani MY. Analysis of IL-10 and IL-6 gene polymorphisms and their serum levels in patients with brucellosis: a case control study. Immunol Investig. 2016:45(2):107-15.

24. Asaei S, Rasouli M, Moravej A. Interleukin-8 but not interleukin- 6 variant may affect susceptibility to brucellosis. Iran J Immunol. 2013;10(3):158-66.

25. Bravo MJ, Colmenero JD, Queipo-Ortuno MI, Alonso A, Caballero A. TGFbeta1 and IL-6 gene polymorphism in Spanish brucellosis patients. Cytokine. 2008;44(1):18-21.

26. Chen X, Yan Y, Li P, Yang Z, Qin L, Mo W. Association of GSTP1 -313A/G polymorphisms and endometriosis risk: a meta-analysis of case-control studies. Eur J Obstet Gynecol Reprod Biol. 2013;171(2):362-7.

27. Myhr KM, Vagnes KS, Maroy TH, Aarseth JH, Nyland HI, Vedeler CA. Interleukin-10 promoter polymorphisms in patients with Guillain-Barre syndrome. J Neuroimmunol. 2003;139(1-2):81-3.

28. Bagheri M, Abdi-Rad I, Omrani D, Khalkhali HR. Heterogeneity of cytokine single-nucleotide polymorphisms among the Iranian and in the other eastsouth Asian populations. Transfus Med. 2006;16(3):192-9.

29. Miyazoe S, Hamasaki K, Nakata K, Kajiya Y, Kitajima K, Nakao K, Daikoku M, Yatsuhashi $\mathrm{H}$, Koga M, Yano M, et al. Influence of interleukin-10 gene promoter polymorphisms on disease progression in patients chronically infected with hepatitis B virus. Am J Gastroenterol. 2002;97(8):2086-92.

30. Oral HB, Budak F, Uzaslan EK, Basturk B, Bekar A, Akalin H, Ege E, Ener B, Goral G. Interleukin-10 (IL-10) gene polymorphism as a potential host susceptibility factor in tuberculosis. Cytokine. 2006;35(3-4):143-7.

31. Sankarasubramanian J, Vishnu US, Gunasekaran P, Rajendhran J. Identification of genetic variants of Brucella spp. through genome-wide association studies. Infect Genet Evol. 2017;56:92-8.

\section{Publisher's Note}

Springer Nature remains neutral with regard to jurisdictional claims in published maps and institutional affiliations.

Ready to submit your research? Choose BMC and benefit from:

- fast, convenient online submission

- thorough peer review by experienced researchers in your field

- rapid publication on acceptance

- support for research data, including large and complex data types

- gold Open Access which fosters wider collaboration and increased citations

- maximum visibility for your research: over $100 \mathrm{M}$ website views per year

At BMC, research is always in progress.

Learn more biomedcentral.com/submissions 